Crop Breeding and Applied Biotechnology 12: 132-137, 2012

Brazilian Society of Plant Breeding. Printed in Brazil

\title{
ARTICLE
}

\section{Chemical composition as related to seed color of common bean}

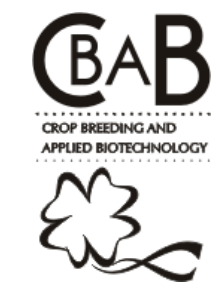

Camila Andrade Silva ${ }^{1 *}$, Ângela de Fátima Barbosa Abreu², Magno Antonio Patto Ramalho ${ }^{1}$ and Lucas Gontijo Silva Maia ${ }^{1}$

Received 22 September 2011

Accepted 4 April 2012

\begin{abstract}
This study aimed to quantify the levels of protein and minerals in common bean lines from the Germplasm Bank of Universidade Federal de Lavras and to investigate the relationship between color and the mineral and protein contents of the beans. One hundred common bean lines with carioca, black and other grain color patterns were assessed for the protein levels and the mineral contents of phosphorus, potassium, calcium, magnesium, copper, manganese, zinc, and iron. Genetic variability was detected among the different groups and also between lines within each group. In general, the protein, iron and zinc contents were highest in the black bean lines. The carioca grain was outstanding for manganese and magnesium and the other grain colors for calcium. Positive correlations between most nutrients were observed. This indicates the possibility of obtaining lines with higher nutritional value by selection.
\end{abstract}

Key words: Phaseolus vulgaris $L$., nutrients, correlation.

\section{INTRODUCTION}

Common bean (Phaseolus vulgaris L.) is a nutrient-rich food that contains nutrients essential for humans, such as proteins, minerals, vitamins (especially B-complex), carbohydrates, and fiber. In Brazil, common bean consumption supplies on average $28 \%$ of the daily protein and $5-11 \%$ of the daily calorie demand (Silva 2010).

The protein quality in common bean is high and many cultivars available for cultivation in Brazil have sufficiently high levels of essential and nonessential amino acids to meet the daily nutritional needs (Ribeiro et al. 2007), according to standards of the Food and Agriculture Organization FAO - (FAO 1998). The protein content of common beans is about half of the content in soybean, while the protein digestibility is higher (78.70\%) (Pires et al. 2006).

For minerals, the main bioavailable sources are foods of animal origin (Costa and Liberato 2003). However, in view of the high cost, they are inaccessible to many people. In view of the high mineral content in the relatively cheap seeds, the consumption of common beans is beneficial to health (Mesquita et al. 2007, Ribeiro et al. 2008, Jost et al. 2009) and can be a means of prevention of a number of mineral deficiencies. The high nutritional quality of common beans and their importance in human nutrition has aroused the interest of national and international breeding programs to verify the existence of variability for these nutrients in their genebanks (Mesquita et al. 2007, Ribeiro et al. 2008, Bassinello et al. 2010). As lines with higher nutritional quality are identified, improvement programs that combine a high nutritional quality with agronomic traits of interest can be initiated.

The type of common beans consumed in different regions differs, especially with regard to grain color. In the Zona da Mata of Minas Gerais, e.g, black or red beans are preferred. In other regions the carioca bean is predominant. This preference is often explained by some factor associated with the chemical composition. However, no studies have been published comparing the chemical composition of representative samples of the different bean color patterns.

In the over 40 years since the beginning of the common bean breeding program of the Federal University of Lavras (UFLA) in 1970, many common bean lines have been collected, selected and stored in the germplasm bank. As there is no information about the chemical composition of the grains of these lines, this study was conducted with the objective of quantifying the protein and mineral levels from a representative sample of these lines and to investigate the relations between seed color and protein and mineral contents.

\footnotetext{
${ }^{1}$ Universidade Federal de Lavras (UFLA), C.P. 3037, 37.200-000, Lavras, MG, Brazil. *E-mail: camilaagro01@yahoo.com.br

${ }^{2}$ Embrapa Arroz e Feijão/UFLA
} 


\section{MATERIAL AND METHODS}

One hundred lines of the Federal University of Lavras (UFLA) Common Bean Germplasm Bank (51 with carioca, 13 with black and 36 with other grain colors) were sown in an experimental field of UFLA, in the southern region of the state of Minas Gerais (lat 21 ${ }^{\circ} 14^{\prime} \mathrm{S}$, long 45 $59^{\circ}$ W, 919 $\mathrm{m}$ asl). The seeds were sown in plots with two $2-\mathrm{m}$ rows, spaced $0.50 \mathrm{~m}$ apart, in the dry season (sowing in February 2009). Fertilization consisted of $400 \mathrm{~kg} \mathrm{ha}^{-1} \mathrm{NPK}$ fertilizer (8- N; 28- $\mathrm{P}_{2} \mathrm{O}_{5 ;} 16-\mathrm{K}_{2} 0$ ) at sowing and $150 \mathrm{~kg} \mathrm{ha}^{-1}$ of ammonium sulfate were top dressed, 25 days after sowing. In this way, $62 \mathrm{~kg} \mathrm{ha}^{-1} \mathrm{~N}$ was applied to the areas. Sprinkler irrigation was applied when necessary.

After harvest, three 50-g seed samples per plot were analyzed in a completely randomized design for the protein and mineral contents ( $\mathrm{P}, \mathrm{K}, \mathrm{Ca}, \mathrm{Mg}, \mathrm{Cu}, \mathrm{Mn}, \mathrm{Zn}$, and $\mathrm{Fe}$ ). For this purpose, the seeds were air-dried to a moisture content of approximately $13 \%$. Each sample was ground in a micro-mill (particle size $<1 \mathrm{~mm}$ ), stored in completely sealed plastic bags, labeled, and refrigerated until laboratory tests. The chemical analyses were performed in the leaf analysis laboratory of the UFLA Chemistry Department.

The protein content was quantified based on the total $\mathrm{N}$ content, by the Kjeldahl method, which consists in heating the $\mathrm{N}$ substance in concentrated sulfuric acid in the presence of a catalyst, so that $\mathrm{N}$ and $\mathrm{H}$ present are converted into ammonium salt. Nitrogen in the form of ammonia is removed in the distillation stage. The distillate is then titrated and the $\mathrm{N}$ content of the sample determined, which is converted to crude protein by the factor 6.25 (AOAC 2005).

For the mineral analysis, nitroperchloric digestion was carried out with $0.5 \mathrm{~g}$ of each sample. At the end of the digestion, the extract volume was completed with deionized water to $15 \mathrm{~mL}$. This digestion removes the elements from the organic compounds of the sample or adsorbed to them. $\mathrm{Ca}, \mathrm{Mg}, \mathrm{Cu}, \mathrm{Mg}, \mathrm{Fe}$, and $\mathrm{Zn}$ contents were determined by atomic absorption spectroscopy, using a SpectrAA 110 model (Varian Inc.), calibrated for each element under specific conditions of wavelength, slit width and gas mixture. $\mathrm{P}$ and $\mathrm{S}$ were analyzed by UV spectrophotometry in a Perkin Elmer Lambda 25 UV/Vis and $\mathrm{K}$ by flame emission photometry in a Micronal B262 unit. For all analyses, the procedures described by Malavolta et al. (1997) were used. After the analysis, the data were corrected to a dry basis by the method of moisture content, measured by the water loss from the sample at a drying temperature of $100-105{ }^{\circ} \mathrm{C}$ (AOAC 2005).
The data of the chemical analyses of the 100 lines were subjected to analysis of variance, according to the following statistical model, considering all effects random, except the mean: $Y_{i j}=\mu+1_{i}+e_{i j}$, where: $Y_{i j}$ : value observed in the line, within the replication $j(j=1,2,3) ; \mu$ : general mean of the experiment; $l_{\mathrm{i}}$ : effect of line $i$, where $i=1,2, \ldots, 100 ; e_{i j}$ : experimental error associated with observation $Y_{i j}$, assuming that errors are independent and normally distributed with mean 0 and variance $\sigma_{\mathrm{e}}^{2}$. For the statistical analyses the softwares Genes (Cruz 2006) and SAS Institute (2008) were used.

The selection accuracy was estimated by the methodology proposed by Resende and Duarte (2007). Means were compared by the Scott-Knott (1974) grouping test. The heritability was also estimated (Bernardo 2002), considering that the selection would be based on the means of the lines and confidence intervals, according to Knapp et al. (1985). The correlation coefficients between nutrients were estimated by the methodologies of Vencovsky and Barriga (1992).

To obtain a selection index involving the data of all nutrients, the sum of the standardized variables $(Z)$ was estimated (Mendes et al. 2009). As variable $Z$ assumes negative and positive values, the value three was added to make all values positive. In this case, the mean of the lines would come to be three instead of zero. Analysis of variance of $\sum Z$ was performed and the coefficient of variation of $Z$ (CVZ) per line estimated.

\section{RESULTS AND DISCUSSION}

Initially it was found that all accuracy estimates were high (>90\%) (Table 1), indicating good experimental precision (Resende and Duarte 2007). The source of variation of lines and of the lines of each color group differed significantly from each other $(\mathrm{P} \leq 0.01)$ (Table 1). This result indicates the existence of genetic variability between the different groups and also between the lines of each group.

The existence of a difference between the lines for all nutrients may also be detected by the estimates of the mean amplitude of variation of line means. The difference was especially significant for $\mathrm{Mn}, \mathrm{Zn}$ and Fe. Several studies in the literature quantified the nutritional contents of common bean (Osborn 1988, Maldonado and Sammám 2000, Araújo et al. 2003, Mesquita et al. 2007, Ribeiro et al. 2007). The averages for the minerals $\mathrm{P}, \mathrm{Cu}$ and $\mathrm{Mn}$ found in this study were higher than previously reported (Barampama and Simard 1993), whereas the average contents of protein and the other minerals were similar to those reported in other studies (Osborn 1988, Mesquita et al. 2007). This variation can be ascribed to the genotype and environmental conditions (Ribeiro et al. 2007). 
Table1. Summary of the analysis of variance, heritability estimates with their lower (LL) and upper limits (UL), accuracy $\left(\hat{r}_{\hat{g} g}\right)$ and general mean for protein and mineral (P, K, Ca, Mg, Cu, Mn, Zn, and Fe) contents of the 100 tested common bean lines of the Common Bean Germplasm Bank

\begin{tabular}{|c|c|c|c|c|c|c|c|c|c|c|}
\hline \multirow[b]{2}{*}{ SV } & \multirow[b]{2}{*}{$\mathrm{df}$} & \multicolumn{9}{|c|}{ MS } \\
\hline & & Protein & $\begin{array}{l}\text { Phospho- } \\
\text { rus }\end{array}$ & $\begin{array}{l}\text { Potas- } \\
\text { sium }\end{array}$ & Calcium & $\begin{array}{l}\text { Magne- } \\
\text { sium }\end{array}$ & Copper & Manganese & Zinc & Iron \\
\hline Lines & 99 & $15.0400 * *$ & $0.0100 * *$ & $0.0500 * *$ & $0.0600^{* *}$ & $0.0010^{* *}$ & $16.4900^{* *}$ & $98.6400^{* *}$ & $152.2600^{* *}$ & $1061.8100^{* *}$ \\
\hline between carioca grain lines & 52 & $14.1200 * *$ & $0.0100 * *$ & $0.0500 * *$ & $0.0300 * *$ & $0.0007 * *$ & $15.5500^{* *}$ & $90.3200 * *$ & $153.4700^{* *}$ & $1228.8000^{* *}$ \\
\hline between black grain lines & 12 & $8.1000^{* *}$ & $0.0030^{* *}$ & $0.0300 * *$ & $0.0600 * *$ & $0.0010 * *$ & $15.9300^{* *}$ & $97.2200^{* *}$ & $141.9600^{* *}$ & $1203.6300 * *$ \\
\hline $\begin{array}{l}\text { between colored grain } \\
\text { lines }\end{array}$ & 33 & $17.1600^{* *}$ & $0.0080^{* *}$ & $0.0500^{* *}$ & $0.0900^{* *}$ & $0.0010^{* *}$ & $18.4500^{* *}$ & $116.5700^{* *}$ & $144.7200^{* *}$ & $758.9900^{* *}$ \\
\hline$h^{2}(\%)$ & & 94.78 & 98.29 & 97.01 & 96.82 & 94.41 & 98.40 & 98.71 & 97.86 & 97.40 \\
\hline LL & & 92.59 & 97.56 & 95.75 & 95.35 & 92.00 & 97.72 & 98.16 & 96.95 & 96.31 \\
\hline UL & & 96.26 & 98.77 & 97.86 & 97.66 & 95.96 & 98.85 & 99.07 & 98.46 & 98.14 \\
\hline$\hat{r}_{g g}(\%)$ & & 97.36 & 99.14 & 98.49 & 98.40 & 97.15 & 99.20 & 99.35 & 98.92 & 98.69 \\
\hline Mean of carioca lines & & $24.54 \mathrm{c}^{1}$ & $0.53 \mathrm{a}$ & $1.81 \mathrm{a}$ & $1.40 \mathrm{~b}$ & $0.26 \mathrm{a}$ & $11.03 \mathrm{~b}$ & $22.98 \mathrm{a}$ & $48.62 \mathrm{~b}$ & $89.00 \mathrm{~b}$ \\
\hline Mean of black lines & & $26.08 \mathrm{a}$ & $0.53 \mathrm{a}$ & $1.83 \mathrm{a}$ & $1.40 \mathrm{~b}$ & $0.24 \mathrm{~b}$ & $11.70 \mathrm{a}$ & $21.65 \mathrm{~b}$ & $52.94 \mathrm{a}$ & $92.21 \mathrm{a}$ \\
\hline
\end{tabular}

** Significant by the $\mathrm{F}$ test at $1 \%$ probability.

${ }^{1}$ Means followed by the same letter in a column belong to the same group. by Scott Knott (1974) analysis. at $5 \%$ probability.

The heritability estimates, all non-zero and above $94 \%$, allow the conclusion that the chance of success with selection for lines with outstanding nutritional quality is high (Table 1). The high heritability estimate obtained in this study must be attributed to the fact that the evaluated lines are from a genebank involving lines with differentiated expression of several traits. Many of these phenotypes are not necessarily related to the acceptance or not of a line by farmers. However, the heritability value indicates that there is a possibility of success in identifying lines with improved nutritional value.

As the sample contained beans of different skin colors, associations were sought between color and nutrient content. The lines were grouped into carioca, black and other color patterns. As already mentioned, significant differences $(\mathrm{P} \leq 0.01)$ between groups were found (Table 1). In general, black bean lines stood out for protein, $\mathrm{Fe}$ and $\mathrm{Zn}$. For $\mathrm{Ca}$, the average levels were higher in the lines of the colored group. Carioca beans, which are the most consumed in Brazil, stood out with highest average
$\mathrm{Mg}$ and $\mathrm{Mn}$ contents. Although the protein content of the black group lines was on average higher (26.08\%), line CIAT-A-257 of the red bean (color) group had the highest protein percentage (30.4\%) (Table 2). It is noteworthy that, as this line is not adapted to the regional growing conditions, it could be used in the hybridization program, in particular with the carioca grain lines, with a view to increase its protein content.

Unfortunately, there is little information in the literature relating nutrient contents with the skin color. Moraghan et al. (2002) observed that the amount of iron found in beans can vary according to the color; they attributed this difference to the tannin content, which is higher in black grain cultivars, since tannins can complex iron. Lombardi-Boccia et al. (1998) reported a higher $\mathrm{Ca}$ content in colored beans, especially in white beans. In this study, where a representative sample of the different colors was used, it can be inferred that a considerable proportion of nutrients must be located in the skin, as reported elsewhere (Leleji et al. 1972, Moraghan and Etchevers 2006, Jost et al. 2009).

Table 2. Classification of 10 common bean lines with the highest and 10 lines with the lowest levels for each nutrient (protein, $\mathrm{P}, \mathrm{K}, \mathrm{Ca}, \mathrm{Mg}, \mathrm{Cu}, \mathrm{Mn}$, $\mathrm{Zn}$, and $\mathrm{Fe}$ )

\begin{tabular}{|c|c|c|c|c|c|c|}
\hline Rank & Line & Protein (\%) & Line & $\mathbf{P}\left(\mathrm{g} 100 \mathrm{~g}^{-1}\right)$ & Line & $\mathbf{K}\left(\mathrm{g} 100 \mathrm{~g}^{-1}\right)$ \\
\hline 1 & Ciat-A-257 & 30.40 & CI-128 & 0.69 & BRS Campeiro & 2.06 \\
\hline 3 & Iapar 81 & 29.25 & $\mathrm{R}-29$ & 0.64 & CNF 05 & 2.04 \\
\hline 5 & Roxo PV & 28.95 & BRSMG Pioneiro & 0.62 & ICA Pijão & 2.00 \\
\hline$\ldots$ & $\ldots$ & $\ldots$ & $\ldots$ & $\ldots$ & $\ldots$ & $\ldots$ \\
\hline 96 & Small White & 20.60 & Batatinha & 0.40 & Bolinha & 1.60 \\
\hline 99 & FP-5.9 & 20.30 & Esal 512 & 0.40 & Flor de Mayo & 1.46 \\
\hline 100 & BRSMG Majestoso & 19.60 & Small White & 0.40 & Esal 521 & 1.45 \\
\hline
\end{tabular}


CA Silva et al.

\begin{tabular}{|c|c|c|c|c|c|c|}
\hline Rank & Line & Ca $\left(g_{\left.100 g^{-1}\right)}\right.$ & Line & $\operatorname{Mg}\left(g_{100 g^{-1}}\right)$ & Line & $\mathbf{C u}\left(\mathrm{mg} \mathrm{kg}^{-1}\right)$ \\
\hline 1 & Safira & 1.80 & Carioca & 0.29 & CI-128 & 15.99 \\
\hline 3 & Fortuna 1895 & 1.76 & AN 910522 & 0.28 & Esal 515 & 15.45 \\
\hline 5 & Ouro & 1.73 & BRSMG Pioneiro & 0.28 & Milionário & 15.10 \\
\hline$\ldots$ & $\ldots$ & $\ldots$ & $\ldots$ & $\ldots$ & $\ldots$ & $\ldots$ \\
\hline 96 & BRSMG Majestoso & 1.24 & AN 910523 & 0.20 & Paraná & 7.40 \\
\hline 99 & MAI-8.9 & 1.21 & Mineiro Precoce & 0.20 & Flor de Mayo & 5.78 \\
\hline \multirow[t]{2}{*}{100} & BRSMG Majestoso & 19.60 & Small White & 0.40 & Esal 516 & 5.76 \\
\hline & & & & & & to be continu \\
\hline Rank & Line & Mn $\left(\mathrm{mg} \mathrm{kg}^{-1}\right)$ & Line & $\mathbf{Z n}\left(\mathrm{mg} \mathrm{kg}^{-1}\right)$ & Line & $\mathbf{F e}\left(\mathrm{mg} \mathrm{kg}^{-1}\right)$ \\
\hline 1 & VR-3 & 36.78 & R-1 & 65.50 & P-180 & 161.50 \\
\hline$\ldots$ & $\ldots$ & $\ldots$ & $\ldots$ & $\ldots$ & $\ldots$ & $\ldots$ \\
\hline 96 & Esal 521 & 13.40 & Mineiro Precoce & 38.81 & BP -28 & 58.95 \\
\hline 97 & Esal 543 & 13.11 & BP -28 & 37.22 & Esal 521 & 58.12 \\
\hline 98 & Esal 516 & 12.45 & Esal 521 & 35.41 & Esal 518 & 56.46 \\
\hline 99 & Iapar 81 & 10.58 & Flor de Mayo & 32.51 & Batatinha & 55.71 \\
\hline 100 & Mineiro Precoce & 9.19 & Esal 516 & 29.33 & Flor de Mayo & 54.20 \\
\hline
\end{tabular}

The correlation estimates (Table 3 ) show a positive association among most nutrients. The same was observed by Beebe et al. (2000). This situation is favorable for improving nutritional quality, indicating the possibility of obtaining lines with higher nutritional value, since selection may be effective for two or more minerals.

To identify lines with superior chemical composition, the selection index based on the sum $\mathrm{Z}\left(\sum \mathrm{Z}\right)$ was used. The line with the highest $\sum \mathrm{Z}$ estimate associated with a small coefficient of variation $(\mathrm{CV})$ is ideal, indicating the line with highest levels of most nutrients and a small variation in the chemical composition as a whole. The $\Sigma \mathrm{Z}$ and $\mathrm{CV}$ estimates were plotted on a graph (Figure 1). It was observed that most of the lines associated high $\sum \mathrm{Z}$ with a low $\mathrm{CV}$ estimate, indicating that the chemical composition of the lines being improved and/or planted in the state is good. Nevertheless,

Table 3. Phenotypic genetic and environmental correlation coefficients between nutrients levels assessed in 100 common bean lines from the Common Bean Germplasm Bank

\begin{tabular}{|c|c|c|c|c|c|c|c|c|c|}
\hline & Protein & Phosphorus & Potassium & Calcium & Magnesium & Copper & Manganese & Zinc & Iron \\
\hline Protein & 1 & $\begin{array}{c}0.35 \pm 0.09^{1} \\
(0.34) * *\end{array}$ & $\begin{array}{c}-0.12 \pm 0.10 \\
(-0.11)\end{array}$ & $\begin{array}{c}0.10 \pm 0.10 \\
(0.10)\end{array}$ & $\begin{array}{c}0.09 \pm 0.11 \\
(0.09)\end{array}$ & $\begin{array}{c}0.29 \pm 0.10 \\
(0.28) * *\end{array}$ & $\begin{array}{c}-0.15 \pm 0.10 \\
(-0.14)\end{array}$ & $\begin{array}{c}0.24 \pm 0.10 \\
(0.24) *\end{array}$ & $\begin{array}{c}-0.17 \pm 0.10 \\
(-0.16)\end{array}$ \\
\hline Phosphorus & 0.14 & 1 & $\begin{array}{c}0.37 \pm 0.09 \\
(0.37) * *\end{array}$ & $\begin{array}{c}-0.14 \pm 0.10 \\
(-0.14)\end{array}$ & $\begin{array}{c}0.32 \pm 0.10 \\
0.32) * *\end{array}$ & $\begin{array}{c}0.27 \pm 0.02 \\
(0.27) * *\end{array}$ & $\begin{array}{c}0.13 \pm 0.10 \\
(0.13)\end{array}$ & $\begin{array}{c}0.53 \pm 0.07 \\
(0.53) * *\end{array}$ & $\begin{array}{l}0.05 \pm 0.10 \\
\quad(0.05)\end{array}$ \\
\hline Potassium & 0.02 & 0.49 & 1 & $\begin{array}{c}0.10 \pm 0.10 \\
(0.10)\end{array}$ & $\begin{array}{c}0.17 \pm 0.10 \\
(0.18)\end{array}$ & $\begin{array}{c}0.44 \pm 0.08 \\
(0.44) * *\end{array}$ & $\begin{array}{c}0.26 \pm 0.10 \\
(0.26) * *\end{array}$ & $\begin{array}{c}0.49 \pm 0.08 \\
(0.49) * *\end{array}$ & $\begin{array}{c}0.31 \pm 0.03 \\
(0.31)^{* *}\end{array}$ \\
\hline Calcium & 0.10 & 0.11 & 0.20 & 1 & $\begin{array}{c}-0.22 \pm 0.10 \\
(-0.20)\end{array}$ & $\begin{array}{c}0.60 \pm 0.07 \\
(0.58) * *\end{array}$ & $\begin{array}{c}0.24 \pm 0.10 \\
(0.24) *\end{array}$ & $\begin{array}{c}0.08 \pm 0.10 \\
(0.08)\end{array}$ & $\begin{array}{l}0.13 \pm 0.10 \\
\quad(0.08)\end{array}$ \\
\hline Magnesium & 0.14 & 0.39 & 0.39 & 0.27 & 1 & $\begin{array}{c}0.08 \pm 0.71 \\
(0.08)\end{array}$ & $\begin{array}{c}0.35 \pm 0.09 \\
(0.35) * *\end{array}$ & $\begin{array}{c}0.19 \pm 0.08 \\
(0.20) *\end{array}$ & $\begin{array}{l}0.03 \pm 0.10 \\
\quad(0.03)\end{array}$ \\
\hline Copper & 0.01 & 0.30 & 0.47 & 0.12 & 0.25 & 1 & $\begin{array}{c}0.52 \pm 0.07 \\
(0.52) * *\end{array}$ & $\begin{array}{c}0.63 \pm 0.06 \\
(0.62) * *\end{array}$ & $\begin{array}{c}0.41 \pm 0.09 \\
(0.41) * *\end{array}$ \\
\hline Manganese & 0.11 & 0.29 & 0.44 & 0.17 & 0.28 & 0.48 & 1 & $\begin{array}{c}0.53 \pm 0.07 \\
(0.52) * *\end{array}$ & $\begin{array}{c}0.37 \pm 0.09 \\
(0.37) * *\end{array}$ \\
\hline Zinc & 0.14 & 0.53 & 0.48 & 0.28 & 0.50 & 0.46 & 0.44 & 1 & $\begin{array}{c}0.55 \pm 0.07 \\
(0.54) * *\end{array}$ \\
\hline Iron & 0.26 & 0.03 & 0.09 & 0.14 & 0.08 & 0.14 & 0.11 & 0.08 & 1 \\
\hline
\end{tabular}

**, * Significant at 1 and 5\% probability by the t test. respectively. ${ }^{1}$ Standard errors of genetic correlations (Holland 2006). In brackets: phenotypic correlation; upper diagonal: genetic correlation and lower diagonal: environmental correlation. 


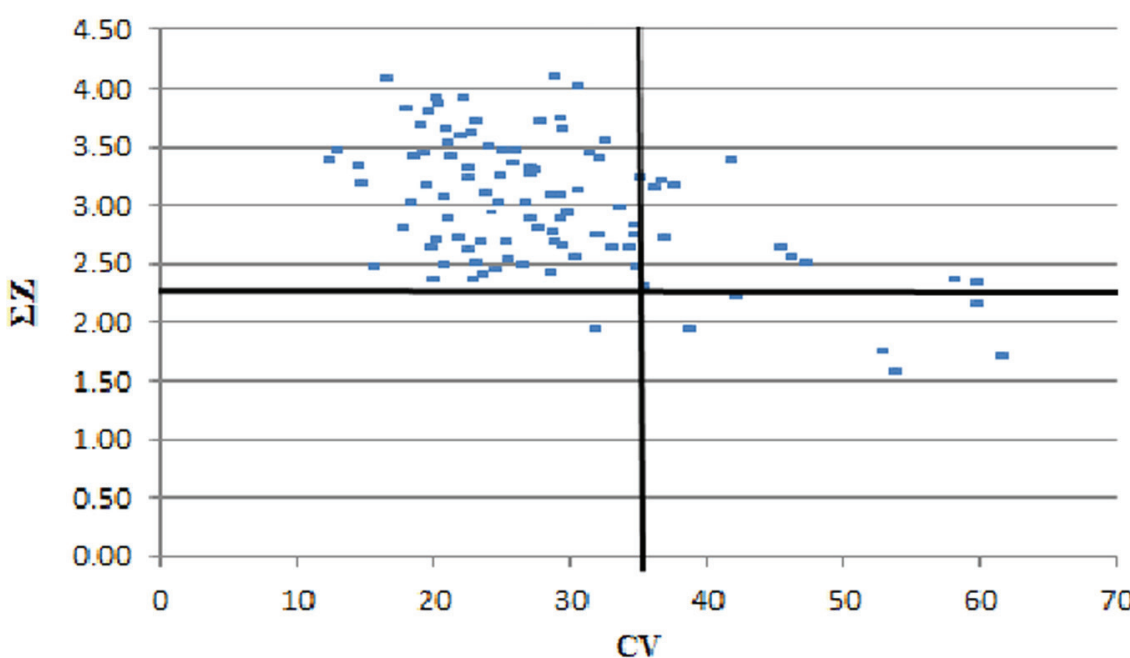

Figure 1. Graphic dispersion of the100 lines evaluated for the sum of standardized variables $\mathrm{Z}\left(\sum \mathrm{Z}\right)$ and the coefficient of variation of each line (CV).
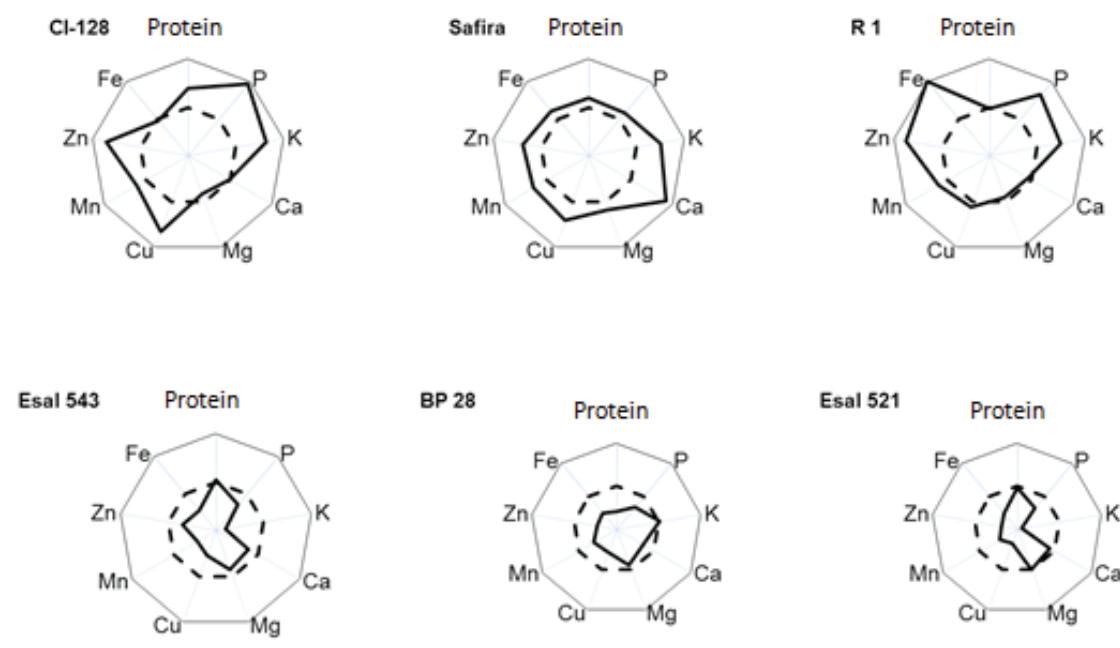

BP 28

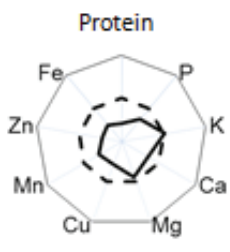

the possibility of a successful selection for each particular nutrient or for the chemical composition as a whole is evident. In this context, the lines CI 128, Safira and RP-1 had the highest $\sum \mathrm{Z}$ estimates and lowest CV (Figure 2). The lines CI-128 and RP-1 belong to the Carioca group and Safira, to the colored group (red coat). On the other hand, the worst lines were ESAL 543 (red skin), BP-28 (Carioca) and ESAL 521 (Carioca).

It is worth noting that although some currently recommended lines had undergone selection for mineral and protein contents, the levels of all nutrients were high, e.g., in the case of the recently recommended BRS Cometa and BRSMG Pioneiro (Moreira et al. 2006, Faria et al. 2007) and RP-1 which is about to be officially recommended (Table 2). These were always ranked among the best 15 lines.

\section{ACKNOWLEDGEMENTS}

The authors thank the CAPES (Brazilian Federal Agency for Support and Evaluation of Graduate Education), the FAPEMIG (Research Foundation of the state of Minas Gerais) and the CNPq (National Council for Scientific and Technological Development) for research grants and financial support.

Figure 2. Graphical representation of the standardized values for protein and minerals $(\mathrm{P}, \mathrm{K}, \mathrm{Ca}$, $\mathrm{Mg}, \mathrm{Cu}, \mathrm{Mn}, \mathrm{Zn}$, and $\mathrm{Fe}$ ) of the three lines with highest and three lines with lowest $\Sigma \mathrm{Z}$ estimates.

\section{Composição química e sua associação com a cor das sementes de feijão comum}

Resumo - Visando a quantificar os teores de proteina e minerais de linhagens de feijão pertencentes ao Banco de Germoplasma da Universidade Federal de Lavras e verificar se existe relação entre a cor do grão e o teor de nutrientes foi realizado o presente trabalho. Foram avaliadas 100 linhagens de feijão dos tipos carioca, preto e cores, quanto aos teores de proteína e dos minerais fósforo, potássio, cálcio, magnésio, cobre, manganês, zinco e ferro. Observou-se variabilidade genética entre os diferentes grupos avaliados e, também, entre as linhagens dentro de cada grupo. Em média, as linhagens de grãos pretos se destacaram para os teores de proteina, ferro e zinco. Já os grãos tipo carioca, para manganês e magnésio e os do tipo cores, para cálcio. Detectou-se correlação positiva entre a maioria dos nutrientes, condição essa favorável para a seleção.

Palavras-chave: Phaseolus vulgaris L., nutrientes, correlação. 
CA Silva et al.

\section{REFERENCES}

Araújo R, Miglioranza E, Montalvan R, Destro D, Gonçalves-Vidigal MC and Moda-Cirino V (2003) Genotype x environment interaction effects on the iron content of common bean grains. Crop Breeding and Applied Biotechnology 4: 269-274.

Association of Official Analytical Chemists - International [AOAC] (2005) Official methods of analysis. $18^{\text {th }}$ ed., AOAC, Gaithersburg.

Barampama Z and Simard RE (1993) Nutrient composition, protein quality and antinutritional factors of some varieties of dry beans (Phaseolus vulgaris L.) grown in Burundi. Food Chemistry 47: 159-167.

Bassinello PZ, Oliveira BR, Lorrana NNN and Wellington MRS (2010) Effect of the environment on zinc and iron levels in common beans. Annual Report of common bean Improvement Cooperative 10: 146-147.

Beebe S, Gonzalez AV and Rengifo J (2000) Research on trace minerals in the common bean. Food and Nutrition Bulletin 21: 387-391.

Bernardo R (2002) Breeding for quantitative traits in plants. Stemma Press, Minnesota, 369p.

Costa NMB and Liberato SC (2003) Biotecnologia na nutrição e saúde. In Costa NMB and Borém A (eds.) Biotecnologia e nutrição: saiba como o DNA pode enriquecer os alimentos. Nobel, São Paulo, p. 71-127.

Cruz CD (2006) Programa Genes: estatística experimental e matrizes. UFV, Viçosa, 285p.

FAO - Junta de Conselho de Especialistas FAO/WHO/ONU (1998) Necessidades de energia e proteína. FAO, São Paulo, 225p.

Faria LC, Peloso MJ, Melo LC, Costa JGC, Rava CA, Diaz JLC, Faria JC, Silva HT, Sartorato A, Bassinello PZ and Trovo JB (2007) BRS Cometa: a carioca grain type common bean cultivar with erect growth habit. Annual Report of common bean Improvement Cooperative 50: 209-210.

Holland JB (2006) Theoretical and biological foundations of plant breeding. In Lamkey KR and Lee M (eds). Plant Breeding: The Arnel R. Hallauer International Symposium. Blackwell Publishing, Ames, p.127-140.

Jost E, Ribeiro ND, Maziero SM, Cerutti TR and Rosa DP (2009) Efeitos gênicos do teor de cálcio em grãos de feijão. Ciência Rural 39: 31-37.

Knapp SJ, Stroup WW and Ross WM (1985) Exact confidence intervals for heritability on a progeny mean basis. Crop Science 25: 192-194.

Leleji OI (1972) Inheritance of crude protein percentage and its correlation with seed yield in beans, Phaseolus vulgaris L. Crop Science 12: 168-171.

Lombardi-Boccia G, Lucarini M, Di Lullo G, Del Puppo E, Ferrari A and Carnovale E (1998) Dialysable, soluble and fermentable calcium from beans (Phaseolus vulgaris L.) as model for in vitro assessment of the potential calcium availability. Food Chemistry 61: 167-172.

Malavolta E, Vitti GC and Oliveira AS (1997) Avaliação do estado nutricional das plantas: princípios e aplicações. Potafos, Piracicaba, 319 p.
Maldonado S and Sammám N (2000) Composición química y contenido de minerales de leguminosas y cereales producidos en el noroeste argentino. Archivos Latino Americanos de Nutrición 50: 195-199.

Mendes FF, Ramalho MAP and Abreu AFB (2009) Índice de seleção para escolha de populações segregantes de feijoeiro comum. Pesquisa Agropecuária Brasileira 44: 1312-1318.

Mesquita FR, Corrêa AD, Abreu CMPA, Lima RAZL and Abreu AFB (2007) Linhagens de feijão (Phaseolus vulgaris L.): composição química e digestibilidade proteica. Ciência e Agrotecnologia 31: 1114-1121.

Moraghan JT and Etchevers JD (2006) Contrasting accumulations of calcium and magnesium in seed coats and embryos of common bean and soybean. Food Chemistry 95: 554-561.

Moraghan JT, Padilla J, Etchevers JD, Grafton K and Acosta-Gallegos JA (2002) Iron accumulation in seed of common bean. Plant and Soil 246: 175-183.

Moreira MA, Barros EG, Carneiro JES, Faleiro FG, Faria LC, Carneiro GES, Peloso MJ, Paula Júnior TJ, Abreu AFB, Ramalho MAP, Melo LC, Santos JB, Rava CA and Costa JGC (2006) BRSMG Pioneiro: new carioca common bean cultivar resistant to anthracnose and rust, for the South of Brazil. Annual Report of common bean Improvement Cooperative 49: 279-280.

Osborn TC (1988) Genetic control of bean seed protein. Critical Reviews in Plant Science 7: 93-116.

Pires CV, Oliveira MGA, Rosa JC and Costa NMB (2006) Qualidade nutricional e escore químico de aminoácidos de diferentes fontes proteicas. Ciência e Tecnologia dos Alimentos 26: 179-187.

Resende MDV and Duarte JB (2007) Precisão e controle de qualidade em experimentos de avaliação de cultivares. Pesquisa Agropecuária Tropical 37: 182-194.

Ribeiro ND, Jost E, Cerutti T, Maziero SM and Poersch NL (2008) Composição de microminerais em cultivares de feijão e aplicações para o melhoramento genético. Bragantia 67: 267-273.

Ribeiro ND, Londero PMG, Cargnelutti Filho A, Jost E, Poersch NL and Mallmann CA (2007) Composição de aminoácidos de cultivares de feijão e aplicações para o melhoramento genético. Pesquisa Agropecuária Brasileira 42: 1393-1399.

SAS Institute (2008) SAS/STAT 9.2 User's guide. SAS Institute, Cary, $584 \mathrm{p}$.

Scott AJ and Knott MA (1974) Cluster analysis method for grouping means in the analysis of variance. Biometrics 30: 507-512.

Silva OF (2010) Consumo per capita de feijão no Brasil, 2010. Available at $<$ http://www.cnpaf.embrapa.br/apps/socioeconomia/docs/arroz/ consumopercapita.htm $>$ Assessed on Jan. 10, 2011.

Vencovsky R and Barriga P (1992) Genética biométrica no fitomelhoramento. Revista Brasileira de Genética, Ribeirão Preto, 496p. 